\title{
Roger Gill
}

\section{Leadership and Spirituality}

\section{Introduction}

The major challenges facing humanity in the third decade of the twenty-first century are spiritual in nature. In meeting them successfully, leadership - spiritual leadership in particular - holds the key. How, then, do spirituality and leadership relate to each other? And how do they together contribute to the performance and well-being of people at work? Let is first consider what they have in common? One answer is that neither term has a single, universally accepted definition. The consequence is that discussion and research concerning spirituality or leadership, or the relationship between them, are at best at high risk of being fragmented and confusing and at the worst fruitless. One antidote to this problem is that any discussion or research concerning spirituality and leadership starts with a proposal for a clear and precise definition of each term and a justification for it.

The purpose of this chapter is to review the state of the art in this field, the challenges ahead, and some suggestions for further research. In doing this I aim to show how spirituality is fundamental to ethical and effective leadership and how spiritual leadership is a development of "conventional” concepts of leadership and spirituality and, as a result, our hope for the future of humanity.

\section{What is Leadership?}

It is commonly said that there are as many definitions of leadership as there are those defining it, and they come from a diverse range of backgrounds - politics, business, public service, the armed forces, sport, the media, the arts and, not least, academia. The quest for a general theory of leadership has been a challenging one and unsuccessful so far but a fascinating and useful one (Goethals \& Sorenson, 2006). The least we can do is to say what we mean by the term and then write about it, as I do with "spirituality". Leadership, like spirituality, and indeed many words, such as beauty and love, is what I call a "Humpty Dumpty" word:

When I use a word, Humpty Dumpty said, in a rather scornful tone, it means just what I choose it to mean - neither more nor less. The question is, said Alice, whether you can make words mean so many different things. The question is, said Humpty Dumpty, which is to be master - that's all.

(Carroll, 1871, p. 87)

My definition, then, is that leadership is showing the way and helping or inducing others to pursue it (Gill, 2011, p. 9). The rationale for this I present elsewhere in detail 
(Gill, 2011, pp. 2-11). In brief, this is, first, that it draws on its etymology, which in this particular case eschews the well-known "etymological fallacy" simply because it is very helpful to do so: etymology can aid clarification where there is confusion and the development of helpful conventions. Second, it represents a distillation of the wide range of extant definitions that have led to misunderstanding and confusion. Leadership is very much more than the basic and most common definition: "a process whereby an individual influences a group of individuals to achieve a common goal” (Northouse, 2013, p. 5). In my model (Gill, 2011, pp. 99-106), showing the way and helping or inducing others to pursue it entails envisioning a desirable future (a vision); promoting a clear purpose or mission, supportive values and intelligent strategies; and empowering and engaging all those concerned - six core themes and practices (Figure 3.1).

An initial version of this model (Gill, 2006) has been independently validated (Rupprecht et al., 2013), and the development and validation of the revised version is underway.

Research into how long-term well-being develops has revealed that job resources predict a high level of job-related well-being. Baran Metin and colleagues (Metin et al., 2016) investigated aspects of empowerment focusing on the relationship between work resources such as autonomy, management and colleague support, and knowledge and skills together with job demands and employee engagement and the role of authenticity - employees' ability to experience their "true selves". They found that authenticity was positively associated with engagement, job satisfaction and job performance and it was also a mediator between job resources (empowerment) and those outcomes.

Research on job resources has explored job control (autonomy and participation in decision making) and supportiveness of the organizational climate in terms of perceptions of the quality of communications and social support (Mäkikangas et al., 2016). Other research also shows that empowerment clearly affects employee engagement and that empowerment is itself a strategy for enhancing employee engagement by providing more meaningful work (Rudolph \& Baltes, 2017; Tanskanen et al., 2016).

Engagement - influencing, motivating or inspiring people to want to do what needs to be done - is the focus of most theories of leadership. However, it is only one piece in the jigsaw puzzle that is leadership. Viewing leadership as only about engaging people at work is a mistake, though it is clearly a necessary and probably the most important element as the consequence of the other five core practices of leadership. Engagement is the extent to which people are motivated or inspired to willingly, even eagerly, give of their discretionary effort over and above doing what they have to do (Gill, 2011, p. 257). Jim Dethmer and colleagues allude to spirit in saying: "[Employee engagement] is all about allowing the flow of life force or energy in individuals and in an organization' [which] 'is directly related to their vitality, passion, focus, creativity, innovation, intuition, clarity, and vision” (Dethmer et al., 2014). 


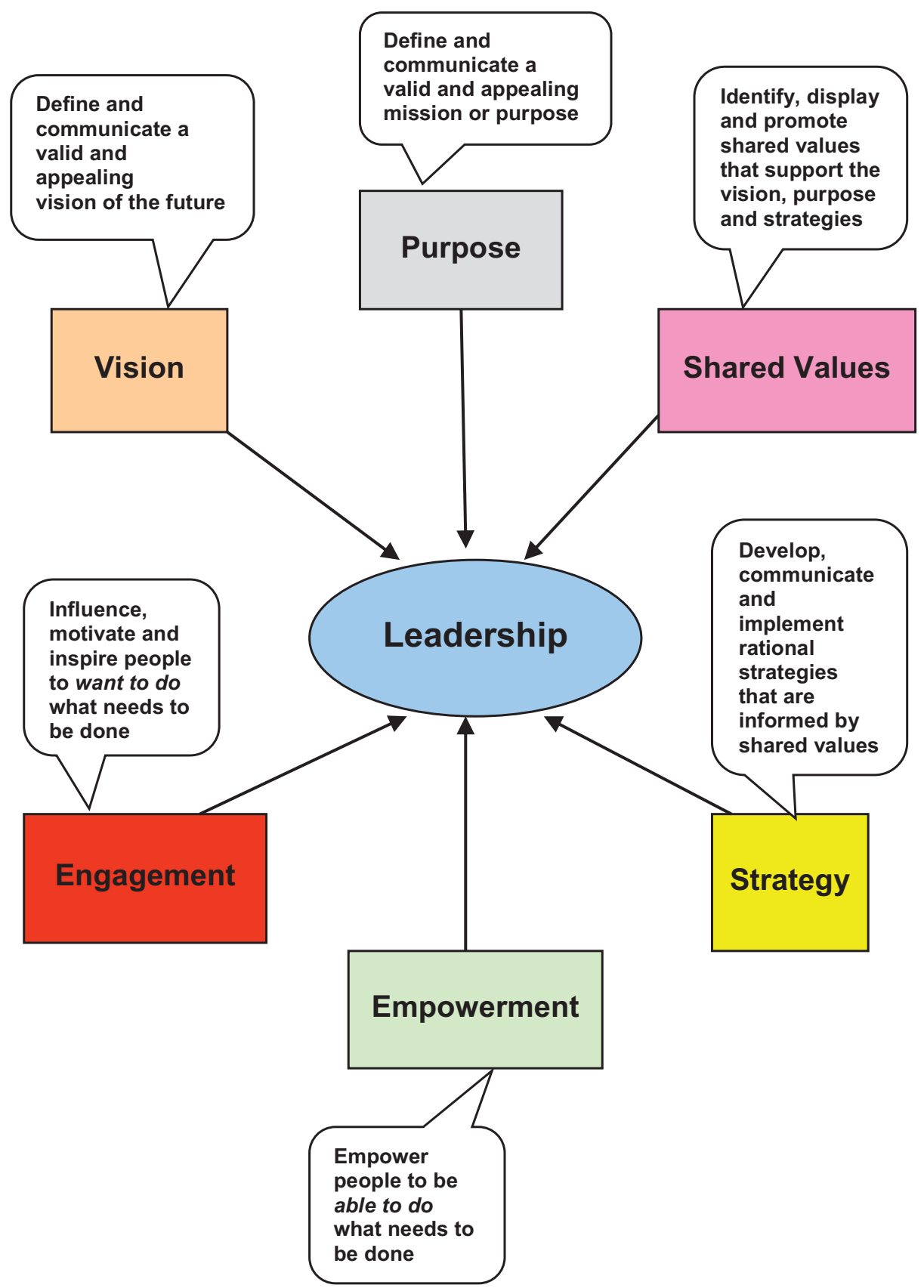

Figure 3.1: A model of six core themes and practices of leadership (Gill, 2011, p. 101). 
Schaufeli and colleagues (2002) found that employee engagement is a positive, fulfilling and affective-motivational state of work-related well-being that is displayed during task performance by:

- Absorption (a cognitive dimension) - maintaining high levels of concentration and involvement

- Dedication (an emotional dimension) - showing high levels of involvement, enthusiasm, inspiration, pride and challenge

- Vigour (a physical dimension) - showing high levels of energy, persistence and effort, despite setbacks and difficulties

Engagement is akin to 'flow': a high degree of engagement is experienced and displayed when there is undistracted, concentrated absorption in an activity which is rewarding in itself as greatly pleasurable, joyous, even rapturous (Nakamura \& Csikszentmihalyi, 2014, pp. 239-263). There is empirical evidence for the mediating effect of meaning in work in the relationship between leadership and engagement (Ghadi et al., 2013). And meaningfulness of work is associated positively with psychological well-being (Arnold et al., 2007). One particular feature of engagement affective commitment (emotional attachment to the organization) - is a direct predictor of employees' psychological well-being (Rivkin et al., 2018). And a positive relationship was found in a study in a large HR services organization in Germany between leaders' own engagement and employee engagement (and performance), with quality of leader-member exchange (LMX) as a mediator (Gutermann et al., 2017). Much evidence exists for the association between employee engagement and employee well-being (Guest, 2014). It is a salutary thought that making money for the owners of a business (its purpose) never was motivating or engaging for its employees.

Much research has focused on why employees are unengaged or disengaged at work. Tomas Chamorro-Premuzic (2016, p. 13) says that research suggests two reasons: those in leadership and management positions do not understand what people really want from work and too many managers are simply incompetent leaders. He says that "employees will be more engaged if their accomplishments are valued by the organisation, if they can form meaningful relationships with their colleagues, and if the rules of conduct are transparent and enforced fairly. Conversely, if they feel unappreciated, isolated or treated unfairly, they will become disengaged, alienated and burnt out.”

There are individual differences in what employees emphasize with respect to their values that influence or determine their behaviour. There is wide variation in the extent to which these differences are understood and responded to by competent leaders and managers. Despite the plethora of expensive and time-consuming leadership development programmes, there are still far too many managers failing as leaders. There are a variety of reasons for this: faulty selection and promotion practices, self-interest, sycophancy, narcissism, vanity, and sheer lack of aptitude 
for leadership. It may well be the case that those who need leadership development most are those who desire and undertake it least. And leadership development programmes appear to be largely designed for those who need it least.

Just like spirituality itself, engagement in practice has its downside. High levels may lead to excessive stress - physical, physiological or psychological - and "presenteeism", whereby an employee attends work despite sickness and not fully functioning because of a high degree of commitment to the job, company or supervisor. There is an association, Kelly McGonigal (2015) says, between stress and meaningfulness: those people who experience stressful life or work events tend to be those who also consider their lives or work to be most meaningful. She notes: "Stress seems to be an inevitable consequence of pursuing goals that feed our sense of purpose". Moreover, leadership that inspires excessive employee engagement is likely to rebound, with increased absence due to sickness (K. Nielsen \& Daniels, 2016).

In her introduction of a special issue on quantum management in the Journal of Management, Spirituality and Religion, Kathryn Pavlovich (2020) brings together current thinking about management and leadership that draws on quantum physics. Quantum management, she say, posits a universe that is an "inexplicable wholeness and connectedness that is governed through entanglement, potentiality, and indeterminism ... [ [and] enables us to radically reframe our understanding of reality through eliminating dichotomies." Quantum management is dependent on our "direct-intuitive experience [so] our personal experiences and practices are central to this shift in awareness." Increased awareness in turn enables us to critique how our actions and behaviour impact on other people and on the world in general. Quantum managers and leaders, it is argued, are then more likely to be able to "focus on enhancing human flourishing and societal well-being".

Quantum theory applied to leadership emerged in the 1990s. Drawing on both Western and Easter thought - quantum leadership entails expanding and transforming human consciousness - awareness of the mind of itself and of the world around us - through enhanced connectedness (Tsao \& Laszlo, 2019). Connectedness, which is more or less a form of mindfulness, entails empathy and compassion. This deepens intuition by combining personal experience with analytical cognitive development. The benefits are many in terms of greater personal effectiveness and well-being at work. Our bodies, minds and spirit are in synchrony - working together simultaneously - and we are in tune with others around us and our natural environment in oneness and wholeness. Examples of its outcomes are greater creativity, collaboration, ability to inspire people, and sustainable transformation. Quantum leadership is also claimed to enhance productivity and profit in business organizations. However, its obviously spiritual aspects are worthy of continuing exploration. 


\section{Spiritual Leadership}

Spirituality concerns the human spirit in the sense of a person's animating principle: spirituality is what drives people. Gilbert Fairholm (1996) suggested a spiritual dimension to leadership as associated with integrity, independence and justice, one that is concerned with meeting people's needs for meaning and value in what they do. Spirituality concerns what relates to, or affects, the emotions and personality of a person in relation to mood, courage, determination and energy. I define spirituality as a synergy of meaning, purpose, beliefs and values (in particular, moral values, or virtues), a sense of community or belonging, and a sense of value or worth in one's life. This synergy animates us in what we seek and do, leading to fulfilment and happiness.

What we now call spiritual leadership may serve both an organization's vision, purpose, values and strategies and its employees' psychological needs (Steger, 2012, p. 232). Indeed, it may be a strategy in its own right. Spiritual leadership encompasses sense making or "meaning making” (Weick, 1995), for example interpreting the environmental complexities - the threats and opportunities of the organization's external environment and the strengths and weaknesses of its internal environment.

No form of effective moral or ethical leadership coerces people to change or compromise deeply held personal values and beliefs. Instead, true spiritual leadership enables employees to find meaning, purpose, belongingness, and a sense of value or worth in their work without imposing this on them. This contributes to employees' spiritual well-being and their happiness in their lives, their performance at work and the performance and well-being of their organization and is the spiritual challenge to leadership today (Gill, 2014). Weber suggested that the old paradigm of the bureaucratic organization is a recipe for "parcelling out the souls of workers" (Weber, 1964) - alienated, powerless, non-fulfilled, estranged from their own selves and emotionally homeless (Blauner, 1964) - characterised by laissez-faire and transactional leadership (management-by-exception and contingent reward) and a lack of transformational leadership (Gill et al., 1998).

Research in a Canadian healthcare setting by Margaret McKee and colleagues found a significant relationship between transformational leadership and employees' mental and spiritual well-being (McKee et al., 2011). This relationship was mediated by workplace spirituality, in particular employees' sense of community. McKee and colleagues (2011) say: "Leaders influence individual well-being through their ability to enhance employees' sense of community in the workplace”. Feeling disconnected from colleagues - from the social aspects of work - may adversely affect well-being at work, e.g. remote working in the virtual organization and 'hot desking'. This has been highlighted in organizations, for example, by the 2020-21 Covid-19 pandemic. Kelly-Ann Allen (2020) explored how social isolation and loneliness are on the rise and describes how meaningful connections are instrumental 
in developing a sense of belonging and our consequential sense of identity and well-being.

How can spiritual leadership induce altruistic love and intrinsic motivation among diverse members within an organization without being regarded as really yet another covert, sophisticated form of corporate exploitation of human vulnerability? $\mathrm{Vu}$ and Gill (2019b) explored an approach to spiritual leadership from a Buddhist perspective that focuses on the power of skilful means to tackle such concerns. In organizations pursuits such as reputation, power, winning, dominance, profit, recognition and even leader-follower relationships are the basis for objectives and expectations. This is known in Buddhism as "attachment". Attachment also characterises preoccupation with physical appearance, fame and celebrity.

In Buddhism any kind of attachment is believed to be a potential source of suffering and other negative consequences. Vu and Gill (2019b) explain how the Buddhist metaphor of "the raft", the emphasis on non-attachment and other Buddhist stories of skilful means contribute to our understanding of spiritual leadership cross-culturally. And they suggest that an issue that could usefully be explored is the cultural difference concerning attitudes to human relationships between the Buddhist emphasis on non-attachment and the Western emphasis on belonging. They also suggest that "fusion leadership" is an approach to integrating Eastern and Western values and mind-sets that may effectively respond to the challenges and dilemmas in spiritual leadership, and leadership more generally, in the context of globalization (Vu \& Gill, 2019a).

Research with hospital nurses in Indonesia showed that for them (a) spiritual leadership has a significant effect on workplace spirituality but not on their job satisfaction or on ihsan behaviour (doing well or doing one's best); (b) workplace spirituality has a significant effect on job satisfaction but not on ihsan behaviour; and (c) job satisfaction has a significant effect on ihsan behaviour (Supriyanto et al., 2016).

We turn now to the first of two major theories of spiritual leadership - servant leadership.

\section{Servant Leadership}

"Servant leadership" is a theory put forward by Robert Greenleaf that postulates that leaders emerge who have the personal characteristics and skills to serve the needs of others - their group, organization or society - at a given time (Greenleaf, 1977). In the Bible it is clear that Moses knew that leadership is about servitude and that his only authority was that granted freely to him by those whom he led (Greenleaf et al., 2003). His inspirational leadership style was, in contemporary terms, illustrative of contingency leadership theory, integrating servant leadership with the leadership of the visionary, the teacher and the shepherd (Ben-Hur \& Jonsen, 2012). 
Socrates and his pupil Xenophon had also seen leadership as serving others and meeting their needs (Adair, 1989, p. 39). And in the Bible St Paul said, “. . . I have made myself every man's servant, to win over as many as possible” (1 Corinthians 9:9). As Major-General (Rtd) Tim Cross has said,““[Jesus] served those who served the cause . . . but He certainly wasn't a doormat, rather a man of tremendous physical and moral courage" (Cross, 1998). It is no coincidence that the motto of the UK's Royal Military Academy at Sandhurst is Serve to Lead and that the Service prayer says, " . . . help us to be masters of ourselves that we may be servants of others, and teach us to serve to lead". An example in the world of business comes from the founder of SouthWest Airlines, Herb Kelleher, who said: "Leadership is being a faithful, devoted, hard-working servant of the people you lead and participating with them in the agonies as well as the ecstasies of life" ( Quoted in Annual Report 1998, Center for Effective Organizations, Marshall School of Business, University of Southern California, Los Angeles, 13.). How many leaders today would see themselves as servants?

Robert Greenleaf by all accounts, Donald Valeri says, was a deeply moral person who was influenced by the Quaker religion (Valeri, 2007). Joe Anderson says Greenleaf also dabbled in Methodism, Unitarianism and Buddhism but was never committed to any particular variety in the Christian tradition and, indeed, once said that he was never "a pious Christian" (Anderson, 2008). Anderson also says that he believed strongly in the capability of the human spirit but never understood the Holy Spirit "that dwells in the heart of those that are born again - those that experience the second birth" (Anderson, 2008). However, he suggests that Greenleaf's ideas about servant leadership are clearly rooted in the Bible and Judeo-Christian heritage. And Valeri (2007) points out that Greenleaf spent his life in a contemplative, spiritual search for truth and meaning, which contributed to his own code of moral behaviour which he never imposed on others, preferring to follow a path of "gentle but firm persuasion". Yet, as Don Frick says, as a natural introvert he never promoted himself (Frick, 2004).

Effective leaders show the way and help or induce others to pursue it (Gill, 2011, p. 9). In helping or inducing employees or followers along the way, servant leaders focus on serving their needs because they care for them. They are concerned for their needs, their aspirations and growth as human beings, and their well-being physical, mental, emotional and spiritual. In its highest manifestation this concern is driven by love for their employees or followers. Altruistic love, disinterested and selfless concern for the well-being of others, is central to servant leadership (Gill \& Negrov, 2021). The virtue of generosity as distinctive in servant leadership reflects the virtue of altruistic love, the basis of all other virtues: "the source from which virtuous leadership comes" (Bocarnea et al., 2018).

The effects of servant leadership on employees' life satisfaction and the mediating role of work engagement and self-esteem in this relationship were investigated in a study of Pakistani employees in a large tractor manufacturing company (Chughtai, 
2018). Servant leadership was found to be positively related to both work engagement and self-esteem, which, in turn, were both positively related to life satisfaction. Work engagement and self-esteem mediated the effects of servant leadership on life satisfaction. Perceptions of servant leadership in Chinese employees have been shown to predict their levels of work engagement (R. Yang et al., 2017). And a meta-analysis of 130 independent studies found that servant leadership had incremental predictive validity over transformational, authentic and ethical leadership and that behavioural outcomes were significantly explained by the level of trust in the leader and the leader-follower relationship (Lee et al., 2020).

A combination of personal traits, motivation to lead and a need to serve others characterizes servant leaders, according to Van Dierendonck (2011). He sees servant leadership as empowering and developing people by expressing humility, authenticity, interpersonal acceptance and stewardship and by providing direction. The mediating processes of trust and fairness are important to encouraging self-actualization, positive job attitudes, performance and a strong organizational focus on sustainability and corporate social responsibility.

The servant leader, Danah Zohar and Ian Marshall (2001, p. 33) say, "serves the ultimate source of meaning and value”. Examples are Mahatma Gandhi, Mother Theresa, Nelson Mandela, Martin Luther King, Jr, and the Dalai Lama. They can equally be called spiritual leaders. Less well known is Katsuhiko Yazaki, the Japanese owner of a global mail-order company, Felissimo. Zohar and Marshall describe how, after becoming wealthy through an inherited business, Yazaki emerged from a monastery with a new self-awareness and a vision of the "proper" role of business as enhancing human happiness (Zohar \& Marshal, 2001, pp. 262-263). He pursued this vision by helping his customers to imagine and achieve more fulfilling lifestyles and investing his money in educational projects and saving the environment.

Servant leadership, despite its appeal to many scholars and practising managers, has not met with universal acclaim. Mitch McCrimmon (2010), a psychologist and executive development consultant, has argued vehemently that servant leadership is paternalistic and, paradoxically, an impediment to employee engagement. He argued that workers need to be empowered to think for themselves and take more ownership, not be "served" by their managers. It may be appropriate, he says, in those situations where leaders are elected - such as politics or clubs where such leaders are expected to serve the wishes, needs or interests of the people they represent or be voted out of office - but not in business, where managers are usually expected to serve their companies' owners first and foremost (or be fired):

The harsh reality in business is that employees are a means to an end. Effective managers will, of course, do all they can to engage, motivate, consider and include employees but that does not amount to being their servant. The truth is that while managers fire employees who aren't performing, no servant can fire his master. Therefore, this sense of servant leadership is interesting but clearly false. 
McCrimmon also says that servant leadership adds no value to a multitude of postheroic leadership models that abandon traditional notions of autocratic and hierarchical leadership in favour of emphasis on teamwork, community, involvement in decision making, caring and selflessness. He says that servant leadership, in transactional analysis terms the nurturing parent (Berne, 1964), also risks the same adverse consequences - demotivation and disengagement - as autocratic leadership (the critical parent). McCrimmon argues as well that servant leadership is less empowering for employees - and therefore less engaging - than employees serving their managers. And a rationale for servant leadership from religion, such as Jesus Christ as a role model, he says, is based merely on personal values rather than on business value. What McCrimmon overlooks or downplays, however, is the possibility that leadership may entail serving an abstract but compelling cause (a mission or purpose) such as one's nation - "Serve to Lead".

Understanding of servant leadership has increased in recent years, according to a systematic review (Nathan et al., 2019), cautioning that there are still "lingering questions" about the conceptual and empirical research that suggests, not surprisingly, an overlap between servant leadership and transformational, ethical and authentic leadership as well as limitations and shortcomings in research design. Perhaps servant leadership makes more of a practical moral and spiritual contribution than a theoretical one at present.

Our second review concerns the most well-known and widely accepted model of spiritual leadership.

\section{Fry's Model of Spiritual Leadership}

Since the turn of the twenty-first century, spiritual leadership has become established as a new approach to leadership, or perhaps a development of it. A central contribution came from Louis (Jody) Fry and his colleagues, arguing for spiritual leadership in embracing commitment to ethical business practices, employee wellbeing, sustainability and social responsibility (Fry, 2003; Fry \& Nisiewicz, 2013; Fry et al., 2017). Fry (2003) believed that the spiritual dimension of human existence had been ignored by leadership scholars in their attention to its behavioural, cognitive, social and emotional aspects.

The importance of the spiritual dimension in human life came into stark relief for him personally during his journey through difficult times, beginning in 1999 and involving a helicopter crash, a car wreck, and a divorce, revealed in an interview in 2013 (Fry, 2013). This experience, together with his discovery and reading of Horton's inspirational book entitled God (Horton, 1950), led him to become a born-again Christian. Horton's view of God was that of "an ideal source of help and object of devotion: a being so much greater, more enduring, and more worthy than ourselves that we may confidently lean on it for support and unreservedly give ourselves to its service" 
(Horton, 1950, pp. 4-5). This view of God as "a higher power on a continuum from atheism (there is no God; one has no sense of calling or membership; all is evil, hopeless and rooted in sorrow, distress, despair, and calamity) to complete pantheism (everything is God; all is good and rooted in joy, peace, serenity" (Fry, 2003, pp. 706-707) formed the basis for his spiritual leadership theory. Despite this allegiance, Fry remains objectively eclectic in his portrayal of religion and spirituality in his writings. Fry (2003) summarises his original model thus:

A causal theory of spiritual leadership . . . within an intrinsic motivation model that incorporates vision, hope/faith, and altruistic love, theories of workplace spirituality, and spiritual survival. The purpose of spiritual leadership is to create vision and value congruence across the strategic, empowered team, and individual levels and, ultimately, to foster higher levels of organizational commitment and productivity.

Fry's model is based on the interaction of intrinsic motivators of leaders and followers that comprise hope, faith, vision and altruistic love (Figure 3.2).

\section{Spiritual Spiritual Well-Being}

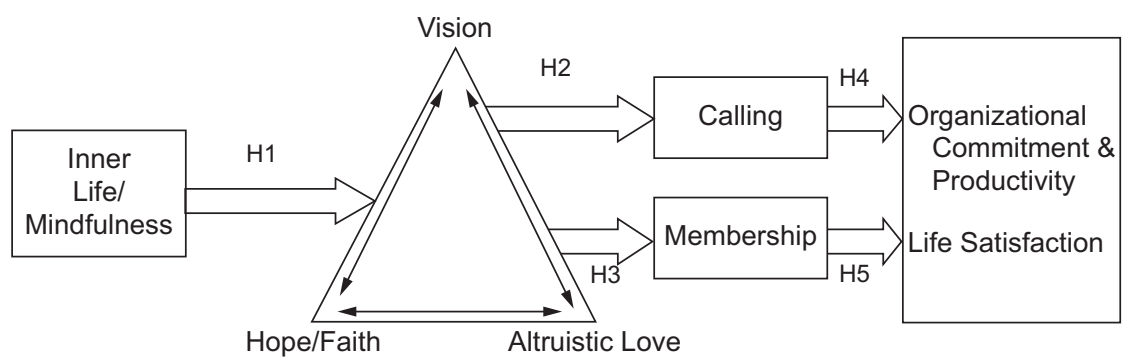

Figure 3.2: Fry's original model of spiritual leadership (Fry et al., 2017, reprinted by permission of the publisher).

Faith, hope and love are the so-called Christian Triad posited by St Paul in 1 Corinthians 13 (Gill \& Negrov, 2021). Altruistic love is characterized by the values of forgiveness, kindness, integrity, empathy and compassion, honesty, patience, courage, trust, loyalty and humility. Hope and faith elicit effort or motivation in terms of endurance, perseverance, pursuit of stretch goals, the desire to "do what it takes", and the expectation of a reward or victory. These motivators determine calling and membership, which in turn (in other versions of the model) lead to organizational and personal outcomes of organizational commitment, employee life satisfaction, corporate social responsibility and financial performance. The latter three outcomes are known as the Triple Bottom Line: people, planet and profit (Fry \& Nisiewicz, 2013, p. 5).

A study of medical laboratory workers by Yang and Fry (2018) using Fry's model found general support for the spiritual leadership model's positive influence 
on organizational commitment and unit productivity and life satisfaction and that organizational membership mediated the relationship between spiritual leadership and employee burnout. A number of other studies have validated Fry's model, not only in the USA and Western cultures but also in a range of other cultures, such as Taiwan (Chen \& Yang, 2012; Chen et al., 2012), China (Chen et al., 2012), South Korea (Hunsaker, 2016), Iran (Javanmard, 2012) and Pakistan (Bodla \& Ali, 2012). In some cases religious beliefs and practices are central to employees in their work. For example, Egel and Fry (2017) have adapted the spiritual leadership model for Islamic leadership based on Islamic tenets (Figure 3.3).

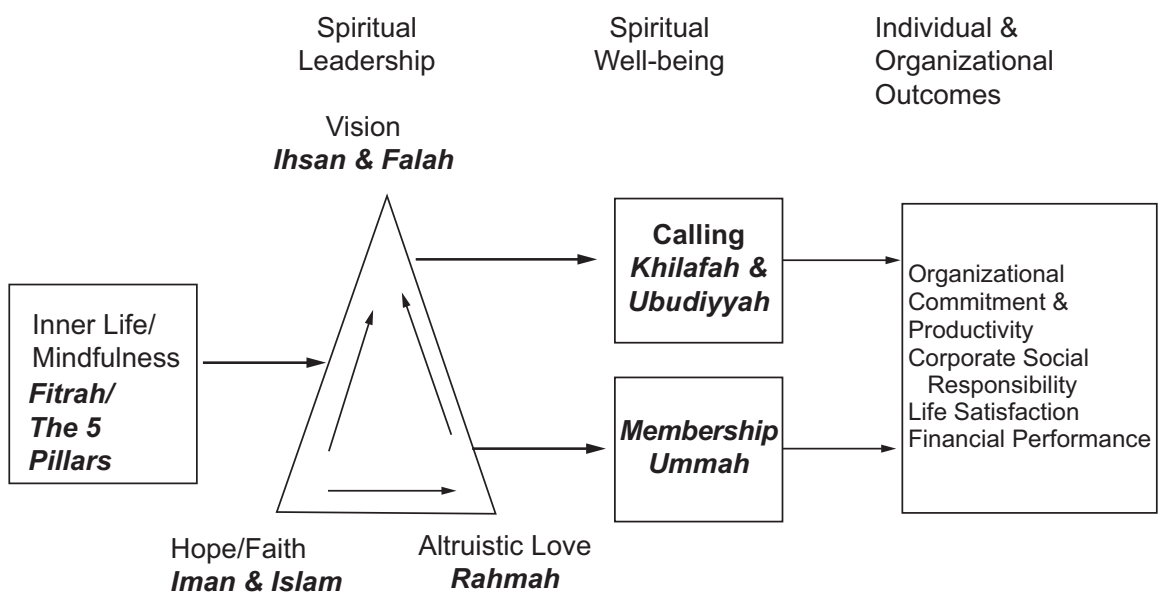

Figure 3.3: Theoretical transposition of the components of Fry's spiritual leadership model into a model for Islamic leadership (Egel \& Fry, 2017, reprinted by permission of the publisher).

In a study of Islamic perspectives on leadership, many aspects of transcendental leadership were found in the Qur'an, particularly prophetic leadership, suggesting the importance of inter-connectedness of the leader, followers and altruism for leadership effectiveness (AlSarhi et al., 2014).

Fry's spiritual leadership theory (SLT) is not without its critics. For example, there are inconsistencies in the definition and use of the term "spirituality" as well as in the different versions of his model that are portrayed. Bruce Avolio and colleagues suggest that Fry does not provide an acceptable working definition of spirituality and that he does not help to explain what constitutes spirituality and leadership and how they relate to each other (Avolio et al., 2009). The underpinning research is criticized for its single-method usage rather than a multi-method approach. Peter Case and colleagues criticize Fry not only for superficial theorizing but also for a too rational and positivistic treatment of spirituality (Case et al., 2012). They argue that Fry's SLT promotes spiritual leadership without a proper philosophical and theological conception of spirituality. 
In 2010 Fry and colleagues introduced a Balanced Scorecard for spiritual leadership, drawing on management and business theory and practice (Fry et al., 2010). Fry's approach to spirituality focuses on organizational commitment, productivity and financial performance, which, in Marjolein Lips-Wiersma's view, is counterintuitive (Lips-Wiersma, 2003). The issue here is whether spirituality has anything to do with material gain - making money. Studies have shown a relationship between spirituality and economic benefits. But just because there may be such a relationship does not justify the hijacking of spirituality specifically for that purpose. Case, French and Simpson (2012) see the SLT as subsumed in consumerism, with the "go-getting" attitude that promotes "egocentric notions of leader/follower relations" and may place "the employee under the performative auspices of managing spirituality". All of this raises ethical questions with its implications of top-down management, the exploitation and control of employees (Rozuel \& McGhee, 2012) that we discussed earlier.

A systematic and critical analysis of 59 empirical studies by Johye Oh and Jia Wang (2020) at Texas A\&M University produced a holistic, comprehensive model of spiritual leadership incorporating Fry's model (Figure 3.4, overleaf).

Inner life as an antecedent of spiritual leadership in this model concerns one's spiritual values and self-reflective practices such as prayer, meditation and religious traditions, in other words one's individual and social identity (Duchon \& Plowman, 2005). “Confucian mindset” refers to social order and harmony. In addition to the factors in Fry's model of spiritual leadership, this factor, in particular social order, appeared significant in the South Korean context (Hunsaker, 2014a). Social order is characterized by the expectation of reciprocal moral obligations and associated behaviour within the social hierarchy of relationships in a group or organization. A cautionary note comes from Denis Diderot, the French philosopher: "Watch out for the fellow who talks about putting things in order. Putting things in order always means getting other people under your control." (Diderot, D. (1796). Harmony is focused on interpersonal attitudes and behavior among individuals within a unit whereby members are expected to pursue conformity and group consensus - a practice increasingly manifest in China but likely to be controversial in other cultures. In the West one is more likely to meet "productive conflict" instead, with its creative outcomes. It is likely that a Confucian mindset is significant to spiritual leadership elsewhere in other parts of East Asia.

However, Mai $\mathrm{Vu}$ (2018), in a study of spiritual leadership in Vietnam, a developing country in transition with a Communist government, suggested that a Buddhist perspective prevalent there today is different not only from that in the West but also from that elsewhere in East Asia despite a hitherto long tradition of Confucianism there as a remnant of Chinese rule. She found that Buddhist-enacted leadership is essentially a process of self-transformation using skillful means - a way of teaching knowledge and applying learning according to the context and the particular people 


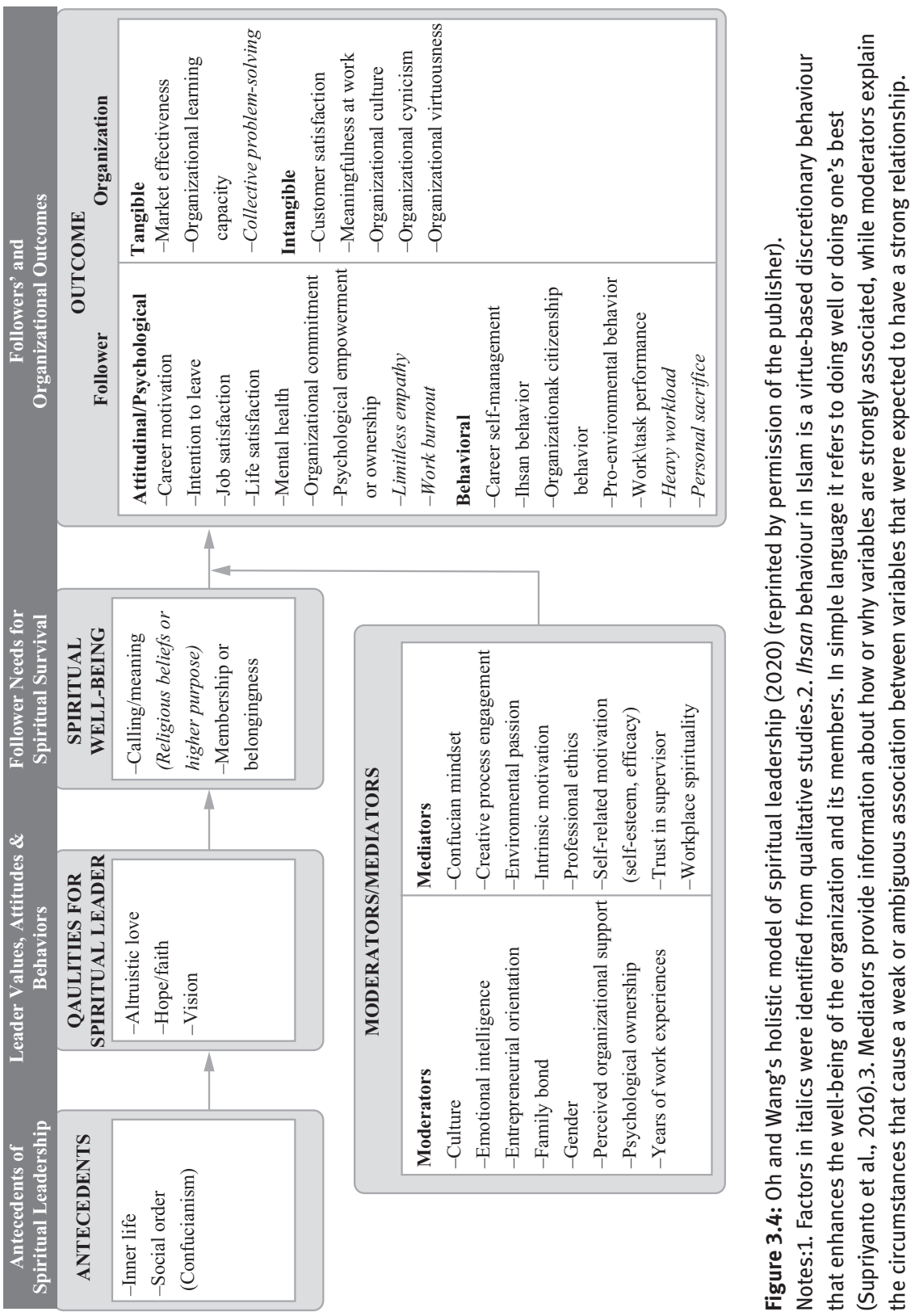


concerned - involving multiple leadership identities and responding to contextual challenges with mindfulness and flexibility.

\section{Spiritual Leadership and Spiritual Intelligence}

Drawing on the concept of spirituality in this chapter, we can define spiritual intelligence (known as SQ) as understanding that human beings have an animating need for purpose (a sense of calling), meaning, and a sense of belonging, virtue and worth in what they seek and do. Spiritual leadership is characterized by responding appropriately to that need. While Howard Gardner (1999, pp. 59-66) expressed concerns that it is difficult to separate spiritual intelligence from its religious connotations and that there was insufficient empirical evidence to separate it from other forms of intelligence, it has gained empirical support and credibility from research in psychology, neurology, anthropology and cognitive science, according to its key proponents, Danah Zohar and Ian Marshall (2001, pp. 11-13). How does SQ relate to emotional intelligence? They contrast SQ with EQ: "My emotional intelligence allows me to judge what situation I am in and then to behave appropriately within it . . . But my spiritual intelligence allows me to ask if I want to be in this particular situation in the first place. Would I rather change the situation, creating a better one?” (Zohar \& Marshal, 2001, p. 5).

Emotional intelligence (known as 'EQ', as distinct from SQ and IQ) is the extent of our self-awareness, our ability to manage our own feelings, our awareness of the needs and feelings of other people, and our ability to respond appropriately (Gill, 2011, pp. 298-299). It is closely related to, if not an aspect of, spiritual intelligence. Zohar and Marshall (2001, p. 285) point out that: "Self-awareness is one of the highest criteria of high spiritual intelligence but one of the lowest priorities of our . . culture.” And Robert Furey (1986, p. 126) suggests that: “A person does not seek to encounter the spiritual dimension of his being until he has developed a healthy sense of humility" (through self-awareness).

Humility, then, is a spiritual value. A growing body of research has shown how humility in leadership is associated with a range of positive outcomes for followers, employees, teams, organizations, and leaders themselves (Swain \& Murray, 2020). Examples of such outcomes are the following:

- Increased follower self-efficacy or confidence, motivation and performance (Mao et al., 2019)

- Reduced emotional exhaustion in high-stress occupations and environments (L. Wang et al., 2018)

- Improved information sharing (Y. Wang et al., 2018)

- Enhanced follower creativity (Gonçalves et al., 2015)

- Greater feedback-seeking behaviour by subordinates (Qian et al., 2018) 
- Improved group and organizational performance and effectiveness (Ou et al., 2018; Rego et al., 2018; Owens \& Hekman, 2016)

- Lower employee turnover (Owens et al., 2013)

- Prosocial and altruistic behaviour in the members of groups, such as helpfulness (LaBouff et al., 2012)

- Encouragement of shared leadership (Chiu et al., 2016; Lindsay et al., 2018)

- Increased self-control in the leader (Tong et al., 2016)Greater liking of leaders by subordinates (Swain, 2018)

- Strengthening of social relationships (R. Nielsen \& Marrone, 2018)

- Greater individual resilience (Brazil \& Dunham, 2018)

- Better overall self-rated physical health (Krause, 2010)

Methods for assessing humility have comprised self-report, implicit association tests, reports by others, and a combination of these (Swain \& Murray, 2020). Though useful, these methods suffer from well-known weaknesses of these methods in general, not least the lack of consensus on the definition of humility. However, there are promising developments ongoing.

Zohar and Marshall (2004) argue that spiritually intelligent leaders can move people from a state of acting from "lower" motivations - fear, greed, anger and selfassertion - to acting from higher forms - exploration, cooperation, personal power, mastery and higher service. This is reminiscent of transformational leadership. Research at Regent University in the USA found that managers in local government who displayed greater servant leadership and spiritual intelligence also reported lower levels of stress and higher levels of workforce engagement with their jobs and organization (Roberts, 2013). Aydın Söylemez and Mustafa Koç (2019) in a study in Turkey found that spiritual intelligence has a positive influence on meaningfulness and life satisfaction. And Muneeba Ali (2019) in Pakistan argues that spiritual leadership based on spiritual intelligence may play an important part in effective change management and organization transformation by contributing to a sense of meaning, well-being, vision and a culture of love in which people feel loved, appreciated and cared for, but that empirical research is needed.

\section{Assessment of Spirituality and Spiritual Leadership}

How do we assess spirituality and develop spiritual leadership in the workplace? Clearly this is useful to do as a basis for understanding and fostering employee empowerment and engagement with the ultimate aim of enhancing or sustaining employee well-being and happiness as well as organizational performance and effectiveness. There are many instruments available for assessing spirituality and spiritual well-being, though they are mostly for clinical or religious situations. 
Much research in spirituality has employed questionnaires custom-designed for the specific topic under investigation, and few instruments serve a universal purpose, which is no doubt related to the issue of a universal definition of spirituality. The same problem besets leadership assessment. Some examples follow.

The Spiritual Well-Being Scale (SWBS) emerged as a development from the quality-of-life movement in the early 1980s, combining two dimensions of life: the existential and the religious (Paloutzian \& Ellison, 1982; Bufford et al., 1991; Genia, 2001; Paloutzian et al., 2012, pp. 353-358). It recognised that the religious dimension had been ignored as an element in well-being and that both dimensions "occupy an important place in human life as motivating and harmonizing forces" (addressed specifically in the Turkish context in a different assessment instrument with the same name) (Ekşi \& Kardaş, 2017). The SWBS has been translated into several languages and consists of two 10-item sub-scales - religious well-being (RWB) and existential well-being (EWB) - covering well-being in a variety of areas, including physical and mental health, psychological adjustment, and assertiveness.

The Spiritual Formation Inventory (SFI), developed by Bruce Baker and Donghun Lee, is non-religious, focused on observable prosocial behaviour, and suitable for workplaces in general (Baker \& Lee, 2020). Spiritual formation is defined as fostering a workplace culture of high engagement. The SFI consists of 19 items assessing three factors - honouring individuals, nurturing relationships, and serving with integrity, which are significantly correlated with workplace engagement, which was measured by the Utrecht Work Engagement Scale (UWES) (Schaufeli et al., 2011). The 17-item UWES itself assesses work engagement characterized by vigour, dedication and absorption in work and is available in several languages.

The Intrinsic Spirituality Scale is a six-item intrinsic spirituality scale that assesses the degree to which spirituality serves as an individual's primary driving force (Hodge, 2003). It is suitable for both theistic and non-theistic populations.

The Spiritual Leadership Scale developed by Louis Fry and colleagues based on his Spiritual Leadership Theory consists of 34 items covering seven factors: vision, hope/faith, altruistic love, meaning/calling, membership, organizational commitment, and productivity (Fry et al., 2005).

Petchsawanga and Duchon's Workplace Spirituality Measure comprising 22 items, developed in Thailand to measure compassion, meaningful work, mindfulness and transcendence (Petchsawang \& Duchon, 2009).

The Integrated Spiritual Intelligence Scale (ISIS). A scale consisting of 83 items and a 45-item, 22-subfactor short form (Amram \& Dryer, 2008).

Servant Leadership Behavior Scale (SLBS-6) (Sen et al., 2019) includes a spiritual dimension, a distinguishing feature that shows servant leadership as a holistic and distinctive leadership approach (Nathan et al., 2019). The inclusion of spirituality faithfully reflects both Greenleaf's initial theorizing (Greenleaf, 1977) and Graham's subsequent analysis (Graham, 1991) that servant leadership relies on spiritual insights and humility as its source of influence. 
The Lee Kum Sheung Center for Health and Happiness at Harvard University (CenterHealthHappiness@hsph.harvard.edu) has compiled a repository of psychological well-being scales that primarily relate to the health sector, though some scales overlap the area of spirituality and may be helpful in relation to spiritual assessment and leadership. The Center defines spiritual well-being together with psychological and social aspects of well-being as constituting subjective wellbeing as a whole.

How spiritual leaders and spiritual leadership develop has been studied in a limited way in three religion-based organizations in Australia. Low and Ayoko (2020) documented the process for 26 spiritual leaders in three such organizations, revealing four phases: (1) awareness of a spiritual calling, associated with interest and opportunity through formal appointment; (2) the learning process associated with personal characteristics, social family and organizational environment, selfdevelopment, a deep relationship with a higher being (God), and formal training; (3) the characteristics of spiritual leaders and spiritual leadership in terms of inspiration, humility, authority, spiritual lifestyle, and follower-based leadership; and (4) outcomes in terms of spiritual leaders' personal development, followers' development, and organizational development. This work needs extending to using larger and wider-ranging samples and covering broader demographics and contexts.

\section{The Challenges Ahead and the Needs for Further Research}

A fundamental contribution of future research to the field of spirituality and leadership would be made by finding satisfactory definitions for both terms that meet consensual approval. I have suggested definitions for both leadership and spirituality for consideration. At least then we would all be researching and writing about the same thing! And that would make the difference between disappointment and delight in the impact of leadership development programmes.

While many studies have shown a positive significant correlation between spirituality (however defined) and spiritual well-being in the population as a whole, a causal link needs to be investigated: is spirituality a cause of spiritual well-being or a consequence of it?

In addition to the well-established quantitative methods that have characterized most research into spirituality and leadership, Oh and Wang say that we now need to supplement these with a diverse range of qualitative methods. They say that, to advance spiritual leadership research, we need more studies using different methodologies and methods. For example, researchers may consider using the case study approach to collect stories of exemplary spiritual leaders, the phenomenological approach to understand spiritual leaders' lived experiences, [and] the grounded 
theory approach to develop new theories and explanations of spiritual leadership (Oh \& Wang, 2020).

Research into how spirituality informs ethical and effective leadership in general can be usefully further explored, focusing on extant theories and models of leadership such as the GILL (General Inventory for Lasting Leadership) (Gill, 2006, 2011; Rupprecht et al., 2013). The GILL, for example, includes the core leadership themes and practices of empowerment and engagement, also identified by Hunsaker (Hunsaker, 2014a), and shared values (in addition to vision, purpose/mission and strategy). Other mediators and moderators can be researched as well as outcomes and measures such as corporate social responsibility, the psychological contract, and organizational performance including profitability and shareholder value (Hunsaker, 2014a), product and service quality, stakeholder satisfaction, and, not least, employee well-being. Faith and hope and altruistic love feature in Fry's and Oh and Wang's models of spiritual leadership, and love has been shown to be an influence for good in leadership (Gill \& Negrov, 2021), so it would be interesting and potentially useful to explore what other values that characterize cultures in which different religions and life philosophies such as Buddhism and humanism prevail inform their concepts and practices of spirituality and spiritual leadership.

Most of the research on spiritual leadership carried out in recent years has concerned Fry's SLT. Most of the empirical studies in the field of spirituality in organizations and spiritual leadership have been quantitative rather than qualitative or mixed-method in nature. And most of these studies have explored the impact on organizational performance and effectiveness and, frequently, financial measures. Benefiel and colleagues say that there is growing concern over the appropriateness of aggregating empirical individual-level data to group and organizational levels in exploring how valid constructs are (Benefiel et al., 2014). To move research on workplace spirituality and spiritual leadership beyond the nascent stage, compared to the more developed management and leadership fields, requires new and more creative multi-method approaches, including qualitative methods. As John Antonakis (2017) says, qualitative research can contribute contextual insights into leadership phenomena, for example in countries in political or economic transition.

Fry and his colleagues (Fry et al., 2017) have recommended further studies of the validity of his spiritual leadership model, among them:

- Longitudinal studies across different populations to test for changes over time in key variables and performance measures

- Studies to explore the efficacy of the model in different national cultures, both religious and secular, political ideologies and stages of economic development

- Studies of outcomes of spiritual leadership at individual, team and organizational levels and the depth of its general validity

- Studies of other stakeholder outcomes, concerning psychological well-being, product and service quality, customer satisfaction, corporate social responsibility, and measures of financial performance and other appropriate performance indicators 
- Use of measures from other leadership theories as control measures, such as such as transformational leadership, authentic leadership, ethical leadership, and servant leadership

Areas of exploration of spirituality at work and spiritual leadership to be addressed include generalisability of theories and models and the influence of context - national, organizational, industry-sectoral, professional and team culture; ideology, politics and religion; and social culture, particularly diversity in respect of gender, black and minority ethnic groups. Consequential issues to be addressed concern bias, unfair discrimination and accommodation (Krishnakumar et al., 2015). And empirical research is needed into the potential contribution of spiritual leadership and spiritual intelligence to organizational change and transformation.

Cheryl Hunt at the University of Exeter in the UK says that, in academia, "discussing and studying spirituality is certainly not widely encouraged" (Hunt, 2020). Reasons for this may be how research publications are viewed within an assessment scheme; the place and status of inter-disciplinary and multi-disciplinary research; the lack of clarity and the confusion in the understanding of spirituality, for example its confusion with spiritualism; and its domination by religion that is perceived in a largely secular audience (in the UK at least). As David Rousseau (2019, p. 19) says, there is "a tendency in science to diminish or devalue what it cannot explain" and that highlighting the significance of people's experiences provides an antidote to this. A renewed encouragement of inter-disciplinary or multi-disciplinary research in the field of spirituality across the arts, humanities, sciences and business is needed. A potential contribution to this in relation to spirituality and science comes from Robinson (2020). Empirical research is needed to validate Robinson's MODI model and its utility in leadership theory and practice and a subsequent assessment system.

Oh and Wang (2020) say that spiritual leadership researchers have focused, almost exclusively, on followers' well-being and other outcomes, overlooking the benefits and consequences for leaders themselves, and they call for research to uncover the mutual benefits of spiritual leadership, especially leaders in work organizations. Very few studies have examined the antecedents of spiritual leadership (Fry, 2003; Dede \& Ayranci, 2014; Fry et al., 2017; Hunsaker, 2014a, 2014b). Oh and Wang (2020) suggest that, given the theoretical background of spiritual leadership in motivation, ethics, religions and values, these elements could be explored in depth as antecedents that predict spiritual leadership behaviour.

Research into spirituality and leadership, including spiritual leadership, in a diverse range of contexts has been sparse so far. This needs to be extended across cultures, nations and industries. This would contribute to a universal understanding of the relationship between spirituality and leadership and cross-cultural differences that exist. For example, the relationship between leadership, spirituality and harmony and altruistic love and how to measure it; other aspects of Confucianism in relation to 
leadership; and that between other Asian philosophies and religions such as Taoism, Hinduism and Buddhism and leadership (Vu \& Gill, 2019a; Hunsaker, 2014a).

Empirical research to validate and develop Oh and Wang's model of spiritual leadership, itself a development of Fry's model, would be worthwhile. Oh and Wang (2020) say: “Only a handful of studies [have] looked at the links between spiritual leadership and other constructs, such as organizational citizenship behavior, psychological empowerment and organizational learning capacity. These constructs clearly relate not only to spiritual leadership but also leadership more generally. More studies are needed.

Earlier I discussed humility in leadership and I mentioned that ways of assessing it are ongoing. Promising areas include assessment of non-verbal cues such as posture and voice and other body language, assessment of observable choices of academic courses, word choice in writing (such as inclusivity of language) and psychometric personality assessment (Swain \& Murray, 2020). More research and development are needed here too.

Investigation is recommended of the relationship between spirituality and Bass and Avolio's Full-Range Leadership model (which is probably the most widely accepted theory of leadership, and in particular the relationship with spirituality of the four "Is": individualised consideration, intellectual stimulation, inspirational motivation and idealised influence (Bass, 1985; Avolio \& Bass, 2001).

A survey by the Chartered Institute of Personnel and Development reported in 2017 showed how employee empowerment and engagement were identified by more than half of human resource professionals as somewhat or very ineffective in the public and private sectors taken together and 40 percent thought that this was a major need for attention over the following three years (Table 3.1):

Table 3.1: Percentage of human resource professionals identifying current effectiveness in empowering and engaging people in the public and private sectors in the United Kingdom.

\begin{tabular}{lcr}
\hline & Empowerment & Engagement \\
\hline Very effective & 5 & 4 \\
\hline Somewhat effective & 42 & 42 \\
\hline Somewhat ineffective & 29 & 35 \\
\hline Very ineffective & 24 & 18 \\
\hline
\end{tabular}

Note: Based on Figure 4, p.15, HR Outlook Survey, Chartered Institute of Personnel and Development, (2017).

Further research is needed on how leaders can develop and introduce an organizational culture that is based on those values, attitudes and competencies that reflect a spiritual philosophy and associated practices. We need to do this through a 
creative mixed-methods research approach, in ways that are both different and better than currently and in exercising leadership ourselves in doing this:

- showing the way - developing and communicating a clear, meaningful, shared vision, shared purpose, shared values, and clear strategies

- helping or inducing people to pursue it through empowering and engaging them in what needs to be done

Fry and Altman (2013) have shown that integration of spiritual leadership into training has led to positive outcomes, such as team empowerment, overcoming resentment, conflict and fear, and consensus-based decision making. Spirituality and leadership therefore can form part of leadership development activity, and further research can help us to do this both effectively and ethically (Oh \& Wang, 2020).

\section{Conclusion}

In her conclusion to the quest for a general theory of leadership, Joanne Ciulla (2006, pp. 232-233) says: "Leadership is ultimately a moral endeavor. When it is done right, leaders help to create the conditions for people to flourish physically, mentally, and as human beings, and they do so without harming others or the world around them." I concur, and I would only add - "and flourish spiritually, whether religious or secular."

Spirituality in leadership and management, and in particular in management education and leadership development programmes and activities, is sorely lacking in both the public sector and business enterprises around the world. The consequence is employee disengagement, spiritual desolation, and psychological and physical ill-health. It is gratifying to see, however, that awareness of this need and attention to it - is gradually increasing. The potential outcome of such efforts is what I view as the supreme goal for humanity: our spiritual well-being. The area of the workplace, work itself and its management are the theatre in which this drama plays out.

Spiritual well-being of people at work is both instrumental for organizational effectiveness, however defined and measured, and a socially and morally responsible and desirable end in itself. Workplace spirituality is causally related in various ways to employees' spiritual well-being. Spiritual leadership creates workplace spirituality and ultimately spiritual well-being, partly, but significantly, through employee empowerment and engagement. We need to help or induce employers and other group and organizational leaders to enhance their understanding and practice of leadership, in particular spiritual leadership, in their organizations. Research, education and training are crucial in this effort to improve the wellbeing of human beings, the organizations that employ them, and ultimately the societies in which we all live. 


\section{References}

Adair, J. (1989). Great Leaders. The Talbot Adair Press.

Allen, K.-A. (2020). The Psychology of Belonging. Routledge.

AlSarhi, N., Salleh, L. M., Mohamed, Z., \& Amini, A. (2014). The West and Islam perspective of leadership. International Affairs and Global Strategy, 18, 42-56.

Amram, Y., \& Dryer, C. (2008). The Integrated Spiritual Intelligence Scale (ISIS): Development and Preliminary Validation. Institute of Transpersonal Psychology.

Anderson, J. (2008, May). The writings of Robert K. Greenleaf: An interpretive analysis and the future of servant leadership. Paper presented at the Servant Leadership Research Roundtable, School of Global Leadership \& Entrepreneurship, Regent University, School of Global Leadership \& Entrepreneurship, Regent University, Virginia Beach, USA.

Antonakis, J. (2017). On doing better science: From thrill of discovery to policy implications. The Leadership Quarterly, 28(1), 5-21.

Arnold, K. A., Turner, N., Barling, J., Kelloway, E. K., \& McKee, M. C. (2007). Transformational leadership and psychological well-being: The mediating role of meaningful work. Journal of Occupational Health Psychology, 12(3), 193-203. https://doi.org/10.1037/1076-8998.12.3.193

Avolio, B. J., \& Bass, B. M. (Eds.). (2001). Developing Potential Across a Full Range of Leadership: Cases on Transactional and Transformational Leadership. Lawrence Erlbaum.

Avolio, B. J., Walumbwa, F. O., \& Weber, T. J. (2009). Leadership: Current theories, research, and future directions. Annual Review of Psychology, 60, 421-449.

Baker, B. D., \& Lee, D. D. (2020). Spiritual formation and workplace engagement: Prosocial workplace behaviors. Journal of Management, Spirituality \& Religion, 17(2), 107-138.

Bass, B. M. (1985). Leadership and Performance Beyond Expectations. Free Press.

Benefiel, M., Fry, L. W., \& Geigle, D. (2014). Spirituality and religion in the workplace: History, theory, and research. Psychology of Religion and Spirituality, 6(3), 175-187. https://doi.org/ $10.1037 / \mathrm{a} 0036597$

Ben-Hur, S., \& Jonsen, K. (2012). Ethical leadership: Lessons from Moses. Journal of Management Development, 31(9), 962-973.

Berne, E. (1964). Games People Play New York. Grove Press.

Blauner, R. (1964). Alienation and Freedom. Chicago University Press.

Bocarnea, M., Henson, J., Huizing, R., Mahan, M., \& Winston, B. E. (2018). Fruitful leadership: Leading with love. In M. Bocarnea, J. Henson, R. Huizing, M. Mahan, \& B. E. Winston (Eds.), Evaluating Employee Performance through Christian Virtues (pp. 7-22). Palgrave Macmillan.

Bodla, M. A., \& Ali, H. (2012). Workplace spirituality: A spiritual audit of banking executives in Pakistan. African Journal of Business Management, 6(11), 3888-3897. https://doi.org/ 10.5897/AJBM10.1242

Brazil, D., \& Dunham, Y. G. (2018). Resilience and overcoming failure. In S. Smith, C. Brazil, B. Britt, \& E. Elinger (Eds.), West Point Leadership. Rowan Technology Solutions.

Bufford, R. K., Paloutzian, R. F., \& Ellison, C. W. (1991). Norms for the spiritual well-being scale. Journal of Psychology and Theology, 19(1), 56-70. https://doi.org/10.1177/ 009164719101900106

Carroll, L. (1871). Through the Looking-Glass and What Alice Found There (New Edition 2003). Puffin Classics.

Case, P., French, R., \& Simpson, P. (2012). From theoria to theory: Leadership without contemplation. Organization, 19(3), 345-361. https://doi.org/10.1177/1350508412437072

Chamorro-Premuzic, T. (2016, March 10). Leaders must learn to behave better to boost engagement. Talent management. Raconteur, 13. 
Chartered institute of personnel and development. (2017). HR Outlook Survey (HR Outlook Survey). Chartered Institute of Personnel and Development.

Chen, C.-Y., \& Yang, C.-F. (2012). The impact of spiritual leadership on organizational citizenship behavior: A multi-sample analysis. Journal of Business Ethics, 105(1), 107-114. https://doi. org/10.1007/s10551-011-0953-3

Chen, C.-Y., Yang, C.-Y., \& Li, C.-I. (2012). Spiritual leadership, follower mediators, and organizational outcomes: Evidence from three industries across two major Chinese societies. Journal of Applied Social Psychology, 42(4), 890-938. https://doi.org/10.1111/j.15591816.2011.00834.x

Chiu, C.-Y. C., Owens, B. P., \& Tesluk, P. E. (2016). Initiating and utilizing shared leadership in teams: The role of leader humility, team proactive personality, and team performance capability. Journal of Applied Psychology, 101(12), 1705-1720. https://doi.org/10.1037/apl0000159

Chughtai, A. A. (2018). Examining the effects of servant leadership on life satisfaction. Applied Research in Quality of Life, 13(4), 873-889. https://doi.org/10.1007/s11482-017-9564-1

Ciulla, J. B. (2006). What we learned along the way: A commentary. In G. R. Goethals \& G. L. J. Sorenson (Eds.), The Quest for a General Theory of Leadership (p. 3968). Edward Elgar Publishing. https://doi.org/10.4337/9781847202932.00017

Cross, T. (1998, July 5). Christian leadership [Speech at Wellbeck College].

Dede, N. P., \& Ayranci, E. (2014). Exploring the connections among spiritual leadership, altruism, and trust in family businesses. Quality \& Quantity, 48(6), 3373-3400. https://doi.org/ 10.1007/s11135-013-9962-x

Dethmer, J., Chapman, D., \& Klemp, K. W. (2014). The 15 Commitments of Conscious Leadership: A New Paradigm for Sustainable Success. Conscious Leadership Group (www.conscious.is) and KWK Kayley Warner Klemp (www.kaleyklemp.com).

Diderot, D. (1796). Supplement to Bougainville's “Voyage."

Duchon, D., \& Plowman, D. A. (2005). Nurturing the spirit at work: Impact on work unit performance. The Leadership Quarterly, 16(5), 807-833. https://doi.org/10.1016/j. leaqua.2005.07.008

Egel, E., \& Fry, L. W. (2017). Spiritual leadership as a model for Islamic leadership. Public Integrity, 19(1), 77-95. https://doi.org/10.1080/10999922.2016.1200411

Ekşi, H., \& Kardaş, S. (2017). Spiritual well-being: Scale development and validation. Spiritual Psychology and Counselling, 2(1), 73-88.

Fairholm, G. W. (1996). Spiritual leadership: Fulfilling whole-self needs at work. Leadership \& Organization Development Journal, 17(5), 11-17. https://doi.org/10.1108/01437739610127469

Frick, D. M. (2004). Robert K. Greenleaf: A Life of Servant Leadership. Berrett-Koehler Publishers.

Fry, L. W. (2003). Toward a theory of spiritual leadership. The Leadership Quarterly, 14(6), 693-727. https://doi.org/10.1016/j.leaqua.2003.09.001

Fry, L. W. (2013, January 7). Interview with National Public Radio, USA, Quidity/Benedictine University. [Interview]. Accessed at www.youtube.com/watch?v=89T8dK9ZpPQ on March 4, 2021

Fry, L. W., \& Altman, Y. (2013). Spiritual Leadership in Action: The CEL Story Achieving Extraordinary Results Through Ordinary People. Information Age Publishing.

Fry, L. W., Latham, J. R., Clinebell, S. K., \& Krahnke, K. (2017). Spiritual leadership as a model for performance excellence: A study of Baldrige Award recipients. Journal of Management, Spirituality \& Religion, 14(1), 22-47. https://doi.org/10.1080/14766086.2016.1202130

Fry, L. W., Matherly, L. L., \& Ouimet, J. -Robert. (2010). The spiritual leadership balanced scorecard business model: The case of the Cordon Bleu-Tomasso Corporation. Journal of Management, Spirituality \& Religion, 7(4), 283-314. https://doi.org/10.1080/14766086.2010.524983

Fry, L. W., \& Nisiewicz, M. S. (2013). Maximizing the Triple Bottom Line Through Spiritual Leadership. Stanford University Press. https://doi.org/10.1515/9780804784290 
Fry, L. W., Vitucci, S., \& Cedillo, M. (2005). Spiritual leadership and army transformation: Theory, measurement, and establishing a baseline. The Leadership Quarterly, 16(5), 835-862. https://doi.org/10.1016/j.leaqua.2005.07.012

Furey, R. J. (1986). So I'm Not Perfect: A Psychology of Humility. Alba House.

Gardner, H. E. (1999). Intelligence Reframed: Multiple Intelligences for the 21st Century. Basic Books.

Genia, V. (2001). Evaluation of the spiritual well-being scale in a sample of college students. International Journal for the Psychology of Religion, 11(1), 25-33. https://doi.org/10.1207/ S15327582IJPR1101_03

Ghadi, M. Y., Fernando, M., \& Caputi, P. (2013). Transformational leadership and work engagement: The mediating effect of meaning in work. Leadership \& Organization Development Journal, 34(6), 532-550.

Gill, R. (2006). Theory and Practice of Leadership. SAGE Publications.

Gill, R. (2011). Theory and Practice of Leadership (2nd ed.). SAGE Publications.

Gill, R. (2014). Spirituality at work and the leadership challenge. Journal for the Study of Spirituality, 4(2), 136-148. https://doi.org/10.1179/2044024314Z.00000000028

Gill, R., Levine, N., \& Pitt, D. C. (1998). Leadership and organizations for the new millennium. Journal of Leadership Studies, 5(4), 46-59. https://doi.org/10.1177/107179199900500405

Gill, R., \& Negrov, A. (2021). Love as an influence for good in leadership. Theology of Leadership, 4(1), 28-53.

Goethals, G. R., \& Sorenson, G. L. J. (Eds.). (2006). The Quest for a General Theory of Leadership. Edward Elgar. https://books.google.at/books?id=NEpkPgAACAAJ

Gonçalves, L., Ribeiro, P., \& Rego, A. (2015, June). How leaders' humility predicts team creativity: An empirical study. Paper presented at the IMC 2015 International Management Conference, Bucharest, Romania.

Graham, J. W. (1991). Servant-leadership in organizations: Inspirational and moral. The Leadership Quarterly, 2(2), 105-119. https://doi.org/10.1016/1048-9843(91)90025-W

Greenleaf, R. K. (1977). Servant Leadership. A Journey into the Nature of Legitimate Power \& Greatness. Paulist Press.

Greenleaf, R. K., Beazley, H., Beggs, J., \& Spears, L. C. (Eds.). (2003). The Servant-Leader Within: A Transformative Path. Paulist Press.

Guest, D. (2014). Employee engagement: A sceptical analysis. Journal of Organizational Effectiveness: People and Performance, 1(2), 141-156.

Gutermann, D., Lehmann-Willenbrock, N., Boer, D., Born, M., \& Voelpel, S. C. (2017). How leaders affect followers' work engagement and performance: Integrating leader-member exchange and crossover theory. British Journal of Management, 28(2), 299-314. https://doi.org/ 10.1111/1467-8551.12214

Hodge, D. R. (2003). The intrinsic spirituality scale: A new six-item instrument for assessing the salience of spirituality as a motivational construct. Journal of Social Service Research, 30(1), 41-61. https://doi.org/10.1300/J079v30n01_03

Horton, W. R. (1950). God (9th printing). Association Press.

Hunsaker, W. D. (2014a). Relationship of confucian values to spiritual leadership in a South Korean context. Asian Social Science, 10(12), 130-141. https://doi.org/10.5539/ass.v10n12p130

Hunsaker, W. D. (2014b). Spiritual leadership in South Korea: A multi-sample analysis of the brokerage sector. Life Science Journal, 11(7), 84-88. http://www.lifesciencesite.com/lsj/ life1107s/014_24409life1107s14_84_88.pdf.

Hunsaker, W. D. (2016). Spiritual leadership and organizational citizenship behavior: Relationship with Confucian values. Journal of Management, Spirituality \& Religion, 13(3), 206-225. https://doi.org/10.1080/14766086.2016.1159974 
Hunt, C. (2020). Celebrating ten years of the Journal for the Study of Spirituality. Journal for the Study of Spirituality, 10(1), 1-5. https://doi.org/10.1080/20440243.2020.1731789

Javanmard, H. (2012). The impact of spirituality on work performance. Indian Journal of Science and Technology, 5(1), 1961-1966.

Krause, N. (2010). Religious involvement, humility, and self-rated health. Social Indicators Research, 98(1), 23-39. https://doi.org/10.1007/s11205-009-9514-x

Krishnakumar, S., Houghton, J. D., Neck, C. P., \& Ellison, C. N. (2015). The "good" and the "bad" of spiritual leadership. Journal of Management, Spirituality \& Religion, 12(1), 17-37. https://doi. org/10.1080/14766086.2014.886518

LaBouff, J. P., Rowatt, W. C., Johnson, M. K., Tsang, J.-A., \& Willerton, G. M. (2012). Humble persons are more helpful than less humble persons: Evidence from three studies. The Journal of Positive Psychology, 7(1), 16-29. https://doi.org/10.1080/17439760.2011.626787

Lee, A., Lyubovnikova, J., Tian, A. W., \& Knight, C. (2020). Servant leadership: A meta-analytic examination of incremental contribution, moderation, and mediation. Journal of Occupational and Organizational Psychology, 93(1), 1-44. https://doi.org/10.1111/joop.12265

Lindsay, D. R., Bond, D., \& Smith, D. (2018). Shared leadership: Understand the power of leader-ful organizations. In D. R. Smith \& J. E. Swain (Eds.), West Point Leadership. Rowan Technology Solutions.

Lips-Wiersma, M. (2003). Making conscious choices in doing research on workplace spirituality: Utilizing the "holistic development model" to articulate values, assumptions and dogmas of the knower. Journal of Organizational Change Management, 16(4), 406-425. https://doi.org/ $10.1108 / 09534810310484163$

Low, J. J. Q., \& Ayoko, O. B. (2020). The emergence of spiritual leader and leadership in religionbased organizations. Journal of Business Ethics, 161(3), 513-530. https://doi.org/10.1007/ s10551-018-3954-7

Mäkikangas, A., Schaufeli, W., Leskinen, E., Kinnunen, U., Hyvönen, K., \& Feldt, T. (2016). Longterm development of employee well-being: A latent transition approach. Journal of Happiness Studies, 17(6), 2325-2345. https://doi.org/10.1007/s10902-015-9696-7

Mao, J., Chiu, C. (Chad), Owens, B. P., Brown, J. A., \& Liao, J. (2019). Growing followers: Exploring the effects of leader humility on follower self-expansion, self-efficacy, and performance. Journal of Management Studies, 56(2), 343-371. https://doi.org/10.1111/joms.12395

McCrimmon, M. (2010). Why servant leadership is a bad idea. Management.Issues, 16 August. https://www.management-issues.com/opinion/6015/why-servant-leadership-is-a-bad-idea/

McGonigal, K. (2015). The Upside of Stress. Vermilion (Random House Group).

McKee, M. C., Driscoll, C., Kelloway, E. K., \& Kelley, E. (2011). Exploring linkages among transformational leadership, workplace spirituality and well-being in health care workers. Journal of Management, Spirituality \& Religion, 8(3), 233-255. https://doi.org/10.1080/ 14766086.2011.599147

Metin, U. B., Taris, T. W., Peeters, M. C. W., van Beek, I., \& Van den Bosch, R. (2016). Authenticity at work - a job-demands resources perspective. Journal of Managerial Psychology, 31(2), 483-499. https://doi.org/10.1108/JMP-03-2014-0087

Muneeba, A. (2019). Effect of spiritual intelligence on effective change management: A review of selected researches. Electronic Research Journal of Social Sciences and Humanities, 1, 30-47.

Nakamura, J., \& Csikszentmihalyi, M. (2014). The concept of flow. In M. Csikszentmihalyi (Ed.), Flow and the Foundations of Positive Psychology (pp. 239-263). Springer Netherlands. https://doi. org/10.1007/978-94-017-9088-8_16

Nathan, E., Mulyadi, R., Sen, S., van Dierendonck, D., \& Liden, R. C. (2019). Servant leadership: A systematic review and call for future research. The Leadership Quarterly, 30(1), 111-132. https://doi.org/10.1016/j.leaqua.2018.07.004 
Nielsen, K., \& Daniels, K. (2016). The relationship between transformational leadership and follower sickness absence: The role of presenteeism. Work \& Stress. An International Journal of Work, Health \& Organisations, 30(2), 193-208. https://doi.org/10.1080/ 02678373.2016.1170736

Nielsen, R., \& Marrone, J. A. (2018). Humility: Our current understanding of the construct and its role in organizations. International Journal of Management Reviews, 20(4), 805-824. https:// doi.org/10.1111/ijmr.12160

Northouse, P. G. (2013). Leadership: Theory and Practice (6th ed.). SAGE Publications.

Oh, J., \& Wang, J. (2020). Spiritual leadership: Current status and agenda for future research and practice. Journal of Management, Spirituality \& Religion, 17(3), 223-248. https://doi.org/ $10.1080 / 14766086.2020 .1728568$

Ou, A. Y., Waldman, D. A., \& Peterson, S. J. (2018). Do humble CEOs matter? An examination of CEO humility and firm outcomes. Journal of Management, 44(3), 1147-1173. https://doi.org/ $10.1177 / 0149206315604187$

Owens, B. P., \& Hekman, D. R. (2016). How does leader humility influence team performance? Exploring the mechanisms of contagion and collective promotion focus. Academy of Management Journal, 59(3), 1088-1111. https://doi.org/10.5465/amj.2013.0660

Owens, B. P., Johnson, M. D., \& Mitchell, T. R. (2013). Expressed humility in organizations: Implications for performance, teams, and leadership. Organization Science, 24(5), 1517-1538. https://doi.org/10.1287/orsc.1120.0795

Paloutzian, R. F., Bufford, R. K., \& Wildman, A. J. (2012). Spiritual well-being scale: Mental and physical health relationships. In M. Cobb, C. Puchalski, \& B. Rumbold (Eds.), Oxford Textbook of Spirituality in Healthcare (pp. 353-358). Oxford University Press.

Paloutzian, R. F., \& Ellison, C. W. (1982). Loneliness, spiritual well-being and the quality of life. In L. A. Peplau \& D. Perlman (Eds.), Loneliness: A Sourcebook of Current Theory, Research and Therapy. Journal of Psychology and Theology (Vol. 11, pp. 330-340).

Pavlovich, K. (2020). Introduction to the special issue on quantum management. Journal of Management, Spirituality \& Religion, 17(4), 299-300. https://doi.org/10.1080/ 14766086.2020.1789309

Petchsawang, P., \& Duchon, D. (2009). Measuring workplace spirituality in an Asian context. Human Resource Development International, 12(4), 459-468. https://doi.org/10.1080/ 13678860903135912

Qian, J., Li, X., Song, B., Wang, B., Wang, M., Chang, S., \& Xiong, Y. (2018). Leaders' expressed humility and followers' feedback seeking: The mediating effects of perceived image cost and moderating effects of power distance orientation. Frontiers in Psychology, 9, 563. https://doi. org/10.3389/fpsyg.2018.00563

Rego, A., Cunha, M. P. e., \& Simpson, A. V. (2018). The perceived impact of leaders' humility on team effectiveness: An empirical study. Journal of Business Ethics, 148(1), 205-218. https:// doi.org/10.1007/s10551-015-3008-3

Rivkin, W., Diestel, S., \& Schmidt, K.-H. (2018). Which daily experiences can foster well-being at work? A diary study on the interplay between flow experiences, affective commitment, and self-control demands. Journal of Occupational Health Psychology, 23(1), 99-111. https://doi. org/10.1037/ocp0000039

Roberts, G. E. (2013). Leadership coping skills: Servant leader workplace spiritual intelligence. Journal of Strategic Leadership, 4(2), 52-69.

Robinson, O. C. (2020). A dialectical approach to understanding the relationship between science and spirituality: The MODI model. Journal for the Study of Spirituality, 10(1), 15-28. https:// doi.org/10.1080/20440243.2020.1726045 
Rousseau, D. (2019). Spirituality and philosophy. Chapter 2. In L. Zsolnai \& B. Flanagan (Eds.), Routledge International Handbook of Spirituality in Society and the Professions. Routledge.

Rozuel, C., \& McGhee, P. (2012). Investigating the convergence of corporate social responsibility and spirituality at work. Australian Journal of Professional and Applied Ethics, 14(1), 47-62.

Rudolph, C. W., \& Baltes, B. B. (2017). Age and health jointly moderate the influence of flexible work arrangements on work engagement: Evidence from two empirical studies. Journal of Occupational Health Psychology, 22(1), 40-58. https://doi.org/10.1037/a0040147

Rupprecht, E. A., Waldrop, J. S., \& Grawitch, M. J. (2013). Initial validation of a new measure of leadership. Consulting Psychology Journal: Practice and Research, 65(2), 128-148.

Schaufeli, W. B., Salanova, M., González-romá, V., \& Bakker, A. B. (2002). The measure of engagement and burnout: A two-sample confirmatory factor analytic approach. Journal of Happiness Studies, 3(1), 71-92. https://doi.org/10.1023/A:1015630930326

Schaufeli, W. B., Salanova, M., González-Romá, V., \& Bakker, A. B. (2011). Utrecht Work Engagement Scale -17. PSycTESTS [Data set]. American Psychological Association. https:// doi.org/10.1037/t07164-000

Sen, S., Nathan, E., Butar Butar, I., Mulyadi, R., \& Castles, S. (2019). SLBS-6: Validation of a short form of the servant leadership behavior scale. Journal of Business Ethics, 156(4), 941-956. https://doi.org/10.1007/s10551-017-3594-3

Söylemez, A., \& Mustafa, K. (2019). Studying spiritual intelligence as a predictor on meaningfulness and life satisfaction. Spiritual Psychology and Counseling, 4(2), 109-122.

Steger, M. F. (2012). Spiritual leadership. In P. C. Hill \& B. J. Dik (Eds.), Psychology of Religion and Workplace Spirituality (pp. 223-238). Information Age Publishing.

Supriyanto, A. S., Soetjipto, B. E., \& Maharani, V. (2016). The effect of spiritual leadership on workplace spirituality, job satisfaction and ihsan behaviour: A study on nurses of Aisyiah Islamic hospital in Malang, Indonesia. International Journal of Applied Business and Economic Research, 14(11), 7675-7688.

Swain, J. E. (2018). Effects of leader humility on the performance of virtual groups. Journal of Leadership Studies, 12(1), 21-37. https://doi.org/10.1002/jls.21552

Swain, J. E., \& Murray, E. D. (2020). Assessing leader humility. Journal of College and Character, 21(3), 204-211. https://doi.org/10.1080/2194587X.2020.1781657

Tanskanen, J., Taipale, S., \& Anttila, T. (2016). Revealing hidden curvilinear relations between work engagement and its predictors: Demonstrating the added value of generalized additive model (GAM). Journal of Happiness Studies, 17(1), 367-387.

Tong, E. M. W., Tan, K. W. T., Chor, A. A. B., Koh, E. P. S., Lee, J. S. Y., \& Tan, R. W. Y. (2016). Humility facilitates higher self-control. Journal of Experimental Social Psychology, 62, 30-39. https://doi.org/10.1016/j.jesp.2015.09.008

Tsao, F. C., \& Laszlo, C. (2019). Quantum Leadership: New Consciousness in Business. Stanford University Press.

Valeri, D. P. (2007). The Origins of Servant Leadership [Dissertation submitted for the degree of Doctor of Philosophy]. Greenleaf University.

van Dierendonck, D. (2011). Servant leadership: A review and synthesis. Journal of Management, 37(4), 1228-1261. https://doi.org/10.1177/0149206310380462

Vu, M. C. (2018). Spiritual leadership: A Buddhist approach [Thesis submitted for the degree of $\mathrm{PhD}$, Durham University]. Durham theses, Durham University. Available at Durham E-Theses Online: http://etheses.dur.ac.uk/12773/

Vu, M. C., \& Gill, R. (2019a). Fusion leadership: A transcultural interpretation and application. International Journal of Cross Cultural Management, 19(2), 140-159. https://doi.org/10.1177/ 1470595819847229 
Vu, M. C., \& Gill, R. (2019b). "Letting go of the raft" - The art of spiritual leadership in contemporary organizations from a Buddhist perspective using skilful means. Leadership, 15(3), 360-380. https://doi.org/10.1177/1742715018761931

Wang, L., Owens, B. P., Li, J. J., \& Shi, L. (2018). Exploring the affective impact, boundary conditions, and antecedents of leader humility. Journal of Applied Psychology, 103(9), 1019-1038. https://doi.org/10.1037/apl0000314

Wang, Y., Liu, J., \& Zhu, Y. (2018). Humble leadership, psychological safety, knowledge sharing, and follower creativity: A cross-level investigation. Frontiers in Psychology, 9, 1727. https://doi.org/10.3389/fpsyg.2018.01727

Weber, M. (1964). The Theory of Social and Economic Organization. The Free Press.

Weick, K. E. (1995). Sensemaking in Organizations (Vol. 3). SAGE Publications.

Yang, M., \& Fry, L. W. (2018). The role of spiritual leadership in reducing healthcare worker burnout. Journal of Management, Spirituality \& Religion, 15(4), 305-324. https://doi.org/ $10.1080 / 14766086.2018 .1482562$

Yang, R., Ming, Y., Ma, J., \& Huo, R. (2017). How do servant leaders promote engagement? A bottom-up perspective of job crafting. Social Behavior and Personality: An International Journal, 45(11), 1815-1827. https://doi.org/10.2224/sbp.6704

Zohar, D., \& Marshal, I. N. (2001). Spiritual Intelligence: The Ultimate Intelligence. Bloomsbury Publishing.

Zohar, D., \& Marshall, I. N. (2004). Spiritual Capital: Wealth We Can Live by. Berrett-Koehler. 
